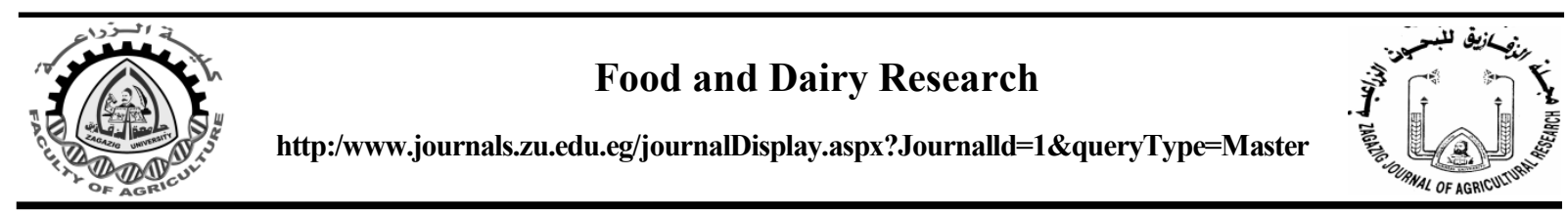

\title{
RELATIONSHIP BETWEEN FOOD INTAKE AND CARDIOVASCULAR DISEASE IN SOME PATIENTS IN ZAGAZIG, SHARKIA GOVERNORATE
}

\author{
Shaimaa M. Mansour*, A.H. Guirguis and Madeha A. El-Shewey \\ Food Sci. Dept., Fac. Agric., Zagazig Univ., Egypt
}

Received: 19/10/2016 ; Accepted: 04/12/2016

\begin{abstract}
This study was carried out during 2010 -2014 years on 20 cardiac patient subjects. They were random selected from Zagazig University Hospitals in Sharkia Governorate. The patients agreed to participate in the controlled diet study. They were already hospitalized and offered the experimental diet and were followed up completely in the hospital. The experiment was planned in such a way that the daily food taken by patients would confirm to certain specifications. Thus the caloric content of the diet and total fat intake where reduced in addition to a considerable cut down of saturated fat, also the cholesterol content were reduced in the diet. The experimental period lasted 6 months with no dropouts. All patients were advised to avoid certain foods, and not allowed to consume any additional foods. Information on the dietary intake of all individuals collected every day. A follow up of the dietary of all individuals were undertaken for the period of the study in order to study the differences in attitude cards of food before and after the start of the study. The results show that reduce the amount of calories from 262.8 grams/day before the start of feeding to 225.4 grams/day after 6 months of feeding and reduce the amount of intake of animal fat and carbohydrates from 52.2 $\mathrm{g} /$ day to $38.6 \mathrm{~g} /$ day and 422.6 to $354.8 \mathrm{~g} /$ day, respectively, to reduce blood content of triglycerides , cholesterol, LDL and HDL from 240.20, 296.40, 128.30 and $114.20 \mathrm{mg} / 100 \mathrm{~g}$, respectively, before the start of feeding to $158,90,239.25,86.40$ and $112.80 \mathrm{mg} / 100 \mathrm{~g}$, respectively. From the results conclude that heart disease linked to nutrition, where the increase in the amount of calories, animal fats saturated and sugar has a significant impact on increasing the concentration of lipids in the blood, and moderate food in the amount of calories and low intake in animal and content of fat on the appropriate amount of unsaturated oils have content a beneficial effect in reducing the proportion of fat in the blood. Saturated fats and oils are considered a serious contributing factor to heart disease.
\end{abstract}

Key words: Patients, cholesterol, heart disease, triglycerides, calories.

\section{INTRODUCTION}

Egypt is the largest Arab country by populations of passives and the second largest economy in the Arab world. The annual average population growth rate was $1.6 \%$ for the 2010 2014 period. The last three decades showed slow paced urbanization in comparison to the expected last pace for the following three decades. Thus dietary energy supplies will have to increase in the following years, as reported by United Nations Populations Statistical Division (UNPSD, 2014). The share of energy supply of both carbohydrates and proteins increased

\footnotetext{
*Corresponding author: Tel. : +20106112993

E-mail address: shaimaamansour@gmail.com
}

during the last two decades in comparison to the contribution of fats, which decreased gradually. The quail ability of major food groups has increased, while the past from supplies of vegetable oils and animal fats decreased gradually. Different surveys in Egypt concluded that primary nutritional problem for many Egyptian adults are a tendency towards obesity. The prevalence of overweight and obesity were $20 \%$ and $10.7 \%$ in Egypt, respectively (Talat and El-Shahat, 2016).

Cardiovascular risk is reduced simply because traditional high carbohydrate diets are low in fat, especially saturated fat, or because 
they promote satiety and thus protect against overweight and obesity. Indeed, it is conceivable that high carbohydrate diets simply act as a marker for some other protective factor (Mann et al., 2007).

Dietary cholesterol recommendations were first promulgated, a large number of longitudinal observational studies and intervention trials have been published on the relation between cholesterol intake and cardiovascular outcomes. Some studies have reported dietary cholesterol increased cardiovascular diseases (CVD) risk (Keys and Parlin, 1998 ; Houston et al., 2011), whereas others reported a decreased risk or no change with higher cholesterol intake (Iso et al., 2001; Harman et al., 2008).

The aim of the present study was planned to determine the potential effect of dietary cholesterol, carbohydrate and fat on incident CVD and on serum concentrations of total cholesterol, Low Density Lipoprotein (LDL) cholesterol, High Density Lipoprotein (HDL) cholesterol, and triglycerides in adults.

\section{MATERIALS AND METHODS}

\section{Subjects}

This study was carried out during $2010-2014$ years on 20 cardiac patient subjects aged from 45 to 60 years (Table 1). They were selected from Zagazig University Hospitals in Sharkia Governorate.

\section{Dietary Study}

Food consumption on pattern and dietary habits were studied as follows:

\section{Food habits}

Dietary history including the food habits was taken during an interview. Special confirm put the dietary habits before and after the diagnosis of the disease.

\section{Daily Diet Intake}

A seven day dietary intake using the recall method. Analysis of daily dietary intake: the average daily consumption was calculated. Nutritive value was determined by using Food Composition Tables of the Nutrient Institute (1996) .The diet was evaluated especially for nutrients that could affect the health of patients. This included the caloric content, amount and type of fat, carbohydrate and protein (Table 2). The cholesterol content of the diet was also calculated .Since some of the cases were already admitted to the hospital, therefor; the prescribed diet was analyzed for its nutrient content.

\section{Controlled Diet Study}

The study sample comprised 10 males and 10 female aged 45 to 60 years old. The patients agreed to participate in the controlled diet study who were already hospitalized were offered the experimental diet and were followed up completely in the hospital .The experiment was planned in such a way that the daily food taken by patients would confirm to certain specifications. Thus the caloric content of the diet and the total fat intake were reduced in addition to a considerable cut down of saturated fatty acids. Thus the cholesterol content was also reduced in the diet.The hospital diet was modified in order to meet the above mentioned specifications. Showed the regular hospital diet and the modified diet used during the experiment, the experimental period lasted 6 months with no dropouts. The method of regular cooking for hospital patients was changed to baking. The type of cooking fat was changed from hydrogenated oil to corn oil. All patients were advised to avoid certain foods. The patient subjects were not allowed to consume additional foods. Information on the dietary intake of all individuals collected every day. A follow up of the dietary of all individuals was undertaken for the period of the study in order to see the differences in attitude card foods before and after the start of the study (Table 3 ).

\section{Laboratory Investigations}

Blood samples were collected from the subjects who agreed to participate in the controlled diet study. Two fasting blood samples were collected from each patients, one before starting the study and the second at the end of the study period. Serum was immediately separated after centrifugation and kept frozen until analyzed for total lipids, cholesterol, HDL, LDL, Sugar (glucose) and triglycerides. Total cholesterol was determined according to the method 
Table 1. Description of patient samples

\begin{tabular}{ccccccccc}
\hline No. & Male & Female & Age & $\begin{array}{c}\text { Marital } \\
\text { status }\end{array}$ & $\begin{array}{c}\text { Number of Occupation } \\
\text { children }\end{array}$ & $\begin{array}{c}\text { Body } \\
\text { weight (kg) }\end{array}$ & $\begin{array}{c}\text { Tall } \\
\text { (cm) }\end{array}$ \\
\hline $\mathbf{1}$ & + & & 48 & Married & 3 & Employee & 87 & 179 \\
$\mathbf{2}$ & + & & 60 & Married & 4 & Free business & 84 & 180 \\
$\mathbf{3}$ & + & & 55 & - & 2 & Employee & 87 & 180 \\
$\mathbf{4}$ & + & & 58 & - & 5 & Farmer & 72 & 175 \\
$\mathbf{5}$ & + & & 54 & Widower & 3 & Employee & 87 & 174 \\
$\mathbf{6}$ & + & & 47 & Married & 2 & Free business & 112 & 173 \\
$\mathbf{7}$ & + & & 59 & Divorcee & 5 & Farmer & 104 & 176 \\
$\mathbf{8}$ & + & & 55 & Married & 4 & Employee & 116 & 188 \\
$\mathbf{9}$ & + & & 45 & Widower & 2 & Free business & 82 & 176 \\
$\mathbf{1 0}$ & + & & 54 & Married & 3 & - & 84 & 171 \\
$\mathbf{1 1}$ & & + & 54 & Divorcee & 5 & Housewife & 112 & 172 \\
$\mathbf{1 2}$ & & + & 57 & Widower & 4 & - & 84 & 168 \\
$\mathbf{1 3}$ & & + & 49 & Married & 4 & - & 84 & 167 \\
$\mathbf{1 4}$ & & + & 57 & Widower & 5 & - & 95 & 164 \\
$\mathbf{1 5}$ & & + & 58 & Married & 5 & - & 94 & 172 \\
$\mathbf{1 6}$ & & + & 54 & Divorcee & 5 & - & 74 & 162 \\
$\mathbf{1 7}$ & & + & 58 & Widower & 5 & - & 94 & 157 \\
$\mathbf{1 8}$ & & + & 42 & Married & 2 & Employee & 74 & 168 \\
$\mathbf{1 9}$ & & + & 45 & - & 3 & - & 84 & 172 \\
$\mathbf{2 0}$ & & + & 51 & - & 3 & - & 93 & 162 \\
\hline
\end{tabular}

Table 2. Change in dietary carbohydrate, animal fat and calories for patients before and after modification during study (intake g/day)

\begin{tabular}{|c|c|c|c|c|c|c|c|c|}
\hline \multirow{2}{*}{ No. } & \multicolumn{2}{|c|}{ Carbohydrate } & \multicolumn{2}{|c|}{ Total fat intake } & \multicolumn{2}{|c|}{ Animal fat } & \multicolumn{2}{|c|}{ Total calories } \\
\hline & Before & After & Before & After & Before & After & Before & After \\
\hline 1 & 348.0 & 325.0 & 84.6 & 74.5 & 44.0 & 38.2 & 2342 & 2265 \\
\hline 2 & 362.0 & 312.2 & 86.4 & 61.2 & 60.0 & 27.4 & 2491 & 2026 \\
\hline 2 & 518.2 & 462.4 & 56.5 & 40.1 & 33.2 & 26.8 & 2693 & 2454 \\
\hline 4 & 492.4 & 344.3 & 96.8 & 67.4 & 78.4 & 42.2 & 3195 & 2275 \\
\hline 5 & 432.2 & 321.5 & 74.6 & 82.2 & 28.0 & $34 . .6$ & 2528 & 2456 \\
\hline 6 & 362.5 & 312.2 & 72.2 & 65.6 & 51.6 & 35.2 & 2444 & 2118 \\
\hline 7 & 438.2 & 456.4 & 98.2 & 52.8 & 78.2 & 35.0 & 2992 & 2426 \\
\hline 8 & 292.6 & 272.5 & 65.4 & 56.6 & 42.6 & 30.2 & 1884 & 2074 \\
\hline 9 & 424.8 & 322.4 & 98.4 & 82.4 & 56.8 & 28.6 & 2345 & 2198 \\
\hline 10 & 452.3 & 326.3 & 62.8 & 80.6 & 44.2 & 56.8 & 2667 & 2752 \\
\hline 11 & 498.2 & 337.6 & 60.6 & 75.2 & 46.4 & 37.4 & 2714 & 2294 \\
\hline 12 & 382.4 & 348.2 & 80.2 & 58.3 & 38.6 & 32.6 & 2462 & 2174 \\
\hline 13 & 373.1 & 356.4 & 88.4 & 86.5 & 52.8 & 58.4 & 2568 & 2568 \\
\hline 14 & 426.4 & 407.6 & 82.2 & 60.2 & 64.7 & 28.2 & 2564 & 2464 \\
\hline 15 & 428.5 & 322.4 & 78.6 & 82.4 & 38.2 & 58.6 & 2682 & 2782 \\
\hline 16 & 422.6 & 343.4 & 82.2 & 66.2 & 62.8 & 32.4 & 2628 & 2262 \\
\hline 17 & 395.2 & 320.2 & 78.4 & 62.4 & 52.2 & 34.5 & 2702 & 2538 \\
\hline 18 & 442.7 & 454.6 & 82.0 & 74.6 & 35.4 & 42.6 & 2746 & 2476 \\
\hline 19 & 418.6 & 312.5 & 94.2 & 78.2 . & 74.2 & 36.4 & 3042 & 2548 \\
\hline 20 & 414.2 & 410.6 & 68.4 & 62.4 & 48.2 & 28.6 & 2578 & 2596 \\
\hline Mean & 422.6 & 354.8 & 80.7 & 70.2 & 52.2 & 38.6 & 262.8 & 225.4 \\
\hline
\end{tabular}


Table 3. Average daily food intake of patients (g/day)

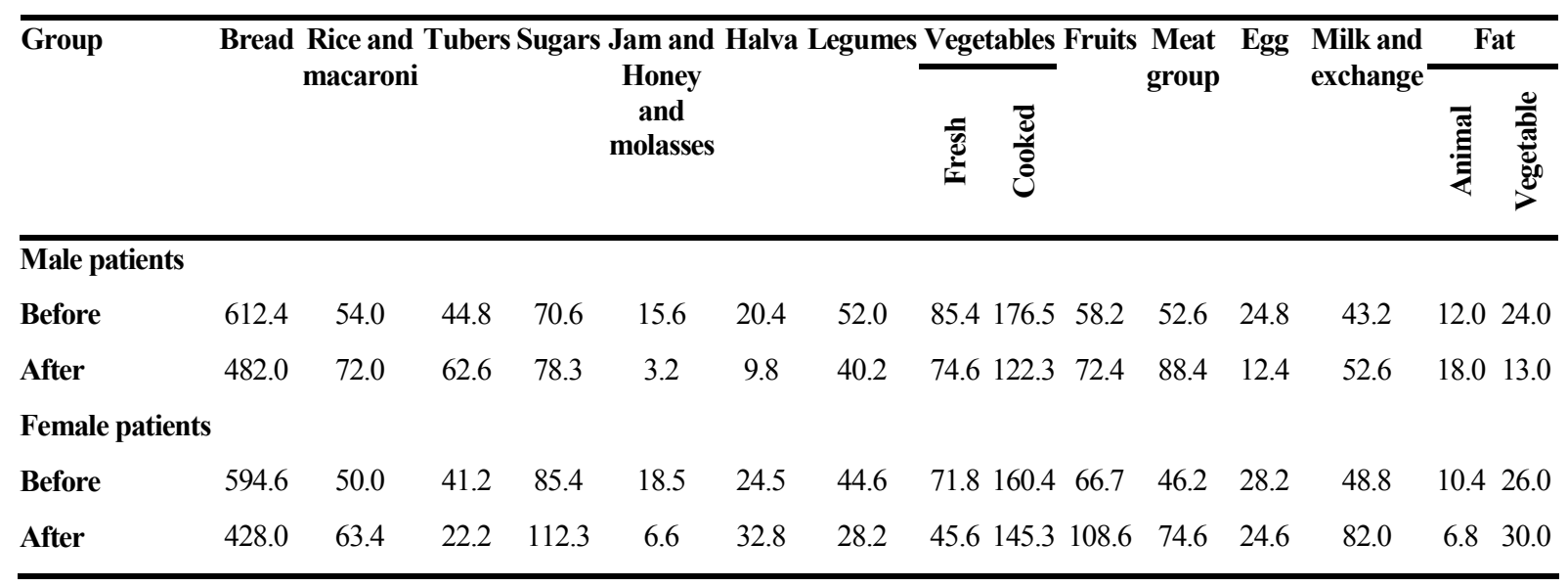

of Enzymatic Colorimeter, Young and Friedman (2001). HDL, LDL, VLDL were determined according to Young (2000). Total lipids and triglycerides were determined according to the method of Devi and Sharma, (2004). Blood glucose level was determined according to the method of Clinical Methods (Trinder, 1969).

\section{Statistical Analyses}

Data were analyzed by statistical analyses with procedures described by Steel and Torries (1980).

\section{RESULTS AND DISCUSSION}

\section{Dietary Study}

Table 4 shows the distribution of calories per day (\%) among different nutrients of patient subjects.

\section{Controlled Diet Study}

Table 5 reveals the serum lipids pattern before and after the modified diet in patients with heart disease. It can be seen that the average values of cholesterol and triglycerides before starting the modified diet were 296.4 and $240.20 \mathrm{mg} / \mathrm{dl}$, respectively. After 2 months following the experimental diet, cholesterol and triglycerides values were lowered to 280.05 and $216,60 \mathrm{mg} / \mathrm{dl}$, respectively while after 4 months they were lowered to 257.50 and $188.80 \mathrm{mg} / \mathrm{dl}$. then they were reached to 239.25 and 158.90 $\mathrm{mg} / \mathrm{dl}$ after 6 months, respectively. The obtained results are similar to that reported by Berger et al. (2015). When they studied the relationship between dietary cholesterol and cardiovascular disease.

The significant differences between the values of cholesterol with advancing time became clear that there are statistically differences at the 0.05 level (Table 5a). These may be due to reducing of animal fat and calories in controlled diet study. The obtained results are similar to that reported by Berger et al. (2015). When they studied the correlation between dietary cholesterol and cardiovascular disease.

The significant differences between the three lipids with advancing time became clear that there are statistically differences at the 0.05 level (Table 5b). These may be due to reducing of animal fat and calories in controlled diet study. The obtained results are similar to that reported by Kumar (2014). When he studied the correlation between anthropometric measurement, lipid profile, dietary vitamins, serum antioxidants, lipoprotein and lipid peroxides in known cases of 345 elderly hypertensive in South Asian aged 56-64 years.

Table 6 shows LDL and HDL pattern before and after intake modified diet for patients with ischemic heart disease. It can be seen that the mean values of LDL and HDL before starting the modified diet were 128.3 and $114.2 \mathrm{mg} / \mathrm{dl}$, respectively. After 2 months following the experimental diet, LDL and HDL values were lowered to117.0 and $112.25 \mathrm{mg} / \mathrm{dl}$, respectively. After 4 months following the experimental diet, LDL and HDL values were again lowered to 104.85 and $112.90 \mathrm{mg} / \mathrm{dl}$, respectively. After 6 
Zagazig J. Agric. Res., Vol. 44 No. (1) 2017

Tables 4. Distribution of calories/day (\%) among different nutrients

\begin{tabular}{|c|c|c|c|c|c|c|}
\hline \multirow[t]{2}{*}{ Group } & \multicolumn{2}{|c|}{ Protein } & \multicolumn{2}{|c|}{ Fat } & \multicolumn{2}{|c|}{ Carbohydrates } \\
\hline & Total & $\overline{\text { Animal }}$ & Total & $\overline{\text { Animal }}$ & Total & $\overline{\text { Animal }}$ \\
\hline Male patients & 12.5 & 3.4 & 20.6 & 11.8 & 67.8 & 15.4 \\
\hline Female patients & 11.6 & 3.8 & 20.4 & 8.1 & 68.5 & 23.2 \\
\hline
\end{tabular}

Table 5. Effect of modified diet on serum lipid levels of patients

\begin{tabular}{|c|c|c|c|c|c|c|c|c|}
\hline \multirow[t]{2}{*}{ No. } & \multicolumn{4}{|c|}{ Total cholesterol (mg/dl) } & \multicolumn{4}{|c|}{ Triglycerides (mg/dl) } \\
\hline & Before & $\begin{array}{l}\text { After } 2 \\
\text { months }\end{array}$ & $\begin{array}{l}\text { After } 4 \\
\text { months }\end{array}$ & $\begin{array}{l}\text { After } 6 \\
\text { months }\end{array}$ & Before & $\begin{array}{l}\text { After } 2 \\
\text { months }\end{array}$ & $\begin{array}{l}\text { After } 4 \\
\text { months }\end{array}$ & $\begin{array}{l}\text { After } 6 \\
\text { months }\end{array}$ \\
\hline 1 & 263 & 212 & 190 & 154 & 136 & 138 & 113 & 121 \\
\hline 2 & 265 & 254 & 278 & 284 & 314 & 270 & 192 & 194 \\
\hline 2 & 245 & 216 & 194 & 216 & 182 & 131 & 136 & 140 \\
\hline 4 & 260 & 245 & 216 & 168 & 182 & 164 & 141 & 130 \\
\hline 5 & 220 & 208 & 200 & 194 & 317 & 260 & 163 & 119 \\
\hline 6 & 312 & 270 & 202 & 236 & 229 & 264 & 168 & 136 \\
\hline 7 & 314 & 300 & 276 & 240 & 210 & 162 & 140 & 132 \\
\hline 8 & 194 & 165 & 216 & 186 & 240 & 192 & 166 & 140 \\
\hline 9 & 274 & 256 & 220 & 190 & 205 & 140 & 132 & 127 \\
\hline 10 & 267 & 184 & 168 & 195 & 194 & 129 & 110 & 132 \\
\hline 11 & 274 & 242 & 294 & 270 & 213 & 219 & 272 & 197 \\
\hline 12 & 297 & 300 & 276 & 207 & 195 & 216 & 276 & 198 \\
\hline 13 & 317 & 285 & 206 & 185 & 265 & 190 & 104 & 160 \\
\hline 14 & 262 & 258 & 270 & 263 & 185 & 174 & 164 & 179 \\
\hline 15 & 362 & 275 & 310 & 220 & 180 & 140 & 150 & 205 \\
\hline 16 & 318 & 305 & 272 & 240 & 250 & 212 & 140 & 170 \\
\hline 17 & 322 & 384 & 269 & 274 & 274 & 264 & 174 & 190 \\
\hline 18 & 274 & 243 & 220 & 184 & 192 & 164 & 133 & 142 \\
\hline 19 & 264 & 248 & 224 & 210 & 185 & 165 & 140 & 132 \\
\hline 20 & 297 & 300 & 284 & 243 & 184 & 182 & 164 & 137 \\
\hline Mean & 296.4 & 280.05 & 257.50 & 239.25 & 240.20 & 216.60 & 188.80 & 158.90 \\
\hline
\end{tabular}

Table 5a. Statistical analyses of the effect of modified diet on serum cholesterol levels of patients

\begin{tabular}{lccc}
\hline Time & Mean & S. Deviation & F. test \\
\hline Before starting & $296.40 \mathrm{a}$ & 46.22 & \\
After 2 months & $280.05 \mathrm{~b}$ & 38.42 & 4.467 \\
After 4 months & $257.50 \mathrm{c}$ & 49.10 & \\
After 6 months & $239.25 \mathrm{~d}$ & 41.52 & \\
LSD & 14.39 & & \\
\hline
\end{tabular}


Table 5b. Statistical analyses of the effect of modified diet on serum triglyceride levels of patients

\begin{tabular}{lccc}
\hline Time & Mean & S. Deviation & F. test \\
\hline Before starting & 220.40 & 46.14 & \\
After 2 months & $216.60 \mathrm{a}$ & 47.06 & 7.703 \\
After 4 months & $188.80 \mathrm{~b}$ & 47.14 & \\
After 6 months & $158.90 \mathrm{c}$ & 45.27 & \\
LSD & 23.15 & & \\
\hline
\end{tabular}

months following the experimental diet, LDL and HDL values were lowered to 86.40 and $112.80 \mathrm{mg} / \mathrm{dl}$, respectively. The obtained results are similar to that reported by Kumar (2014).

The significant differences between the percentages of LDL and HDL with advancing time showed clearly that there are statistically differences at the 0.05 level (Table $6 \mathrm{a}$ and $6 \mathrm{~b}$ ). These may be due to reducing of animal fat, calories and triglycerides in controlled diet study. The obtained results are similar to that reported by Kumar (2014). When he studied the correlation between anthropometric measurement, lipid profile, dietary vitamins, serum antioxidants, lipoprotein and lipid peroxides in known cases of 345 elderly hypertensive in South Asian aged 56-64 years.

Table 7 shows the serum glucose levels pattern before and after the modified diet in patients with ischemic heart disease. It can be seen that the mean values of serum glucose before starting the modified diet was 180.20 $\mathrm{mg} / \mathrm{dl}$. After 2 months following the experimental diet, serum glucose values were lowered and the mean valued to $174.05 \mathrm{mg} / \mathrm{dl}$. After 4 months following the experimental diet serum glucose mean value was lowered to $150.75 \mathrm{mg} / \mathrm{dl}$, after 6 months following the experimental diet, serum glucose mean value was lowered to $145.2 \mathrm{mg} / \mathrm{dl}$. The obtained results are similar to that reported by Mann et al. (2007) when they studied the long-term outcomes of calorie-restricting diets to assess whether dieting is an effective treatment for obesity.

The significant differences between the percentages of serum glucose levels with the advancing time it became clear that there no statistically differences (Table 8). These may be due to reducing of carbohydrates and calories in controlled diet study. The obtained results are similar to that reported by Mann et al. (2007). When they studied the long-term outcomes of calorie-restricting diets to assess whether dieting is an effective treatment for obesity.

\section{Conclusion}

Cardiovascular disease is linked with nutrition. Where food that containing a large amount of calories, unsaturated animal fat and carbohydrates lead to increase triglyceride and cholesterol contents in the blood. While food contents moderate amounts of calories and low in unsaturated animal fat contributes significantly to lower triglyceride and cholesterol contents in the blood and thereby reduce the risk of heart disease. 
Table 6. Effect of modified diet on serum LDL and HDL levels of patients (mg/dl)

\begin{tabular}{|c|c|c|c|c|c|c|c|c|}
\hline \multirow[t]{2}{*}{ No. } & \multicolumn{4}{|c|}{ LDL (mg/dl) } & \multicolumn{4}{|c|}{ HDL (mg/dl) } \\
\hline & Before & $\begin{array}{l}\text { After } 2 \\
\text { months }\end{array}$ & $\begin{array}{l}\text { After } 4 \\
\text { months }\end{array}$ & $\begin{array}{l}\text { After } 6 \\
\text { months }\end{array}$ & Before & $\begin{array}{l}\text { After } 2 \\
\text { months }\end{array}$ & $\begin{array}{l}\text { After } 4 \\
\text { months }\end{array}$ & $\begin{array}{l}\text { After 6 } \\
\text { months }\end{array}$ \\
\hline 1 & 74 & 105 & 83 & 116 & 120 & 90 & 67 & 60 \\
\hline 2 & 187 & 143 & 108 & 81 & 187 & 165 & 150 & 144 \\
\hline 2 & 195 & 140 & 74 & 76 & 75 & 100 & 65 & 93 \\
\hline 4 & 123 & 118 & 70 & 82 & 123 & 92 & 118 & 119 \\
\hline 5 & 117 & 82 & 78 & 85 & 117 & 97 & 135 & 144 \\
\hline 6 & 174 & 89 & 78 & 100 & 174 & 115 & 115 & 88 \\
\hline 7 & 95 & 102 & 108 & 30 & 95 & 118 & 83 & 124 \\
\hline 8 & 75 & 47 & 62 & 187 & 75 & 90 & 107 & 96 \\
\hline 9 & 120 & 80 & 92 & 50 & 120 & 110 & 107 & 93 \\
\hline 10 & 144 & 54 & 40 & 67 & 144 & 100 & 80 & 130 \\
\hline 11 & 107 & 100 & 134 & 82 & 107 & 143 & 104 & 174 \\
\hline 12 & 104 & 107 & 127 & 114 & 104 & 172 & 180 & 127 \\
\hline 13 & 167 & 160 & 70 & 82 & 74 & 94 & 90 & 77 \\
\hline 14 & 194 & 165 & 105 & 74 & 32 & 60 & 96 & 90 \\
\hline 15 & 220 & 44 & 67 & 30 & 220 & 120 & 124 & 140 \\
\hline 16 & 150 & 160 & 82 & 66 & 130 & 120 & 110 & 93 \\
\hline 17 & 104 & 94 & 100 & 84 & 104 & 164 & 143 & 151 \\
\hline 18 & 74 & 113 & 74 & 78 & 74 & 106 & 124 & 147 \\
\hline 19 & 92 & 80 & 74 & 78 & 92 & 113 & 142 & 150 \\
\hline 20 & 78 & 114 & 102 & 92 & 78 & 89 & 116 & 150 \\
\hline Mean & 128.30 & 117.00 & 104.85 & 86.40 & 114.20 & 112.25 & 112.90 & 112.80 \\
\hline
\end{tabular}

Table 6a. Statistical analyses of the effect of modified diet on serum LDL levels of patients

\begin{tabular}{lccc}
\hline Time & Mean & S. Deviation & F. test \\
\hline Before starting & $128.30 \mathrm{a}$ & 28.16 & \\
After 2 months & $117.00 \mathrm{~b}$ & 47.14 & 3.529 \\
After 4 months & $104.85 \mathrm{c}$ & 35.92 & \\
After 6 months & $86.40 \mathrm{~d}$ & 22.88 & \\
LSD & 11.03 & & \\
\hline
\end{tabular}


Table 6b. Statistical analyses of the effect of modified diet on serum HDL levels of patients

\begin{tabular}{lccc}
\hline Time & Mean & S. Deviation & F. test \\
\hline Before starting & $114.20 \mathrm{a}$ & 26.22 & \\
After 2 months & $112.25 \mathrm{~b}$ & 44.00 & 0.002 \\
After 4 months & $112.90 \mathrm{~b}$ & 28.75 & \\
After 6 months & $112.80 \mathrm{~b}$ & 28.79 & \\
LSD & 1.35 & & \\
\hline
\end{tabular}

Table 7. Effect of modified diet on serum glucose levels of patients (mg/dl)

\begin{tabular}{|c|c|c|c|c|}
\hline \multirow[t]{2}{*}{ No. } & \multicolumn{4}{|c|}{ Serum glucose (mg/dl) } \\
\hline & Before & After 2 months & After 4 months & After 6 months \\
\hline 1 & 107 & 102 & 94 & 87 \\
\hline 2 & 317 & 270 & 252 & 265 \\
\hline 2 & 84 & 80 & 89 & 102 \\
\hline 4 & 94 & 101 & 85 & 86 \\
\hline 5 & 194 & 176 & 171 & 162 \\
\hline 6 & 270 & 310 & 184 & 112 \\
\hline 7 & 97 & 84 & 79 & 92 \\
\hline 8 & 108 & 95 & 91 & 84 \\
\hline 9 & 98 & 86 & 76 & 78 \\
\hline 10 & 74 & 82 & 68 & 92 \\
\hline 11 & 362 & 354 & 264 & 288 \\
\hline 12 & 295 & 316 & 282 & 205 \\
\hline 13 & 193 & 164 & 161 & 172 \\
\hline 14 & 218 & 197 & 176 & 107 \\
\hline 15 & 175 & 162 & 174 & 162 \\
\hline 16 & 123 & 194 & 197 & 184 \\
\hline 17 & 374 & 312 & 297 & 264 \\
\hline 18 & 107 & 96 & 92 & 84 \\
\hline 19 & 105 & 94 & 87 & 84 \\
\hline 20 & 210 & 206 & 196 & 194 \\
\hline Mean & 180.20 & 174.05 & 150.75 & 145.20 \\
\hline
\end{tabular}


Zagazig J. Agric. Res., Vol. 44 No. (1) 2017

Table 8. Statistical analyses of the effect of modified diet on serum glucose levels of patients

\begin{tabular}{lccc}
\hline Time & Mean & S. Deviation & F. test \\
\hline 0 Time & $180.20 \mathrm{a}$ & 28.16 & \\
After 2 months & $174.05 \mathrm{~b}$ & 36.00 & 3.112 \\
After 4 months & $150.75 \mathrm{c}$ & 22.65 & \\
After 6 months & $145.20 \mathrm{~d}$ & 24.72 & \\
LSD & 11.44 & & \\
\hline
\end{tabular}

\section{REFERENCES}

Berger, S., G. Raman, R. Vishwanathan, P. Jacques and E. Johnson (2015). Dietary cholesterol and cardiovascular disease: A systematic review and meta-analysis. Ame. J. Clin. Nutr., 102 : 276-94.

Devi, R.K. and D.K. Sharma (2004). Hypolipidemic effect of different extracts of Clerodendron Colebrookianum Walp in normal and high-fat diet fed rats. J Ethnopharmacol, 90: 63-68.

Food Composition Tables for Egypt (1996). Nutrient Institute $1^{\text {st }} \mathrm{Ed}$.

Harman, N.L., A.R. Leeds, and B.A Griffin (2008). Increased dietary cholesterol does not increase plasma low density lipoprotein when accompanied by an energy-restricted diet and weight loss. Eur. J. Nutr., 47 : 287 293.

Houston, D.K., J. Ding, J.S. Lee, M .Garcia, A.M .Kanaya, F.A .Tylavsky, A.B .Newman, M. Visser and S.B. Kritchevsky (2011). Dietary fat and cholesterol and risk of cardiovascular disease in older adults: The Health ABC Study. Nutr. Metab. Cardiovasc., 21: 856-863.

Iso, H., M.J. Stampfer, J.E. Manson, K. Rexrode, F. Hu, C.H. Hennekens, G.A. Colditz, F.E. Speizer and W.C. Willett (2001). Prospective study of fat and protein intake and risk of intraparenchymal hemorrhage in women. Circulation., 103 : 856-863.

Keys, A. and R.W. Parlin (1998). Serum cholesterol response to changes in dietary lipids. Ame. J. Clin. Nutr., 19:175-81.
Kumar, A. (2014). Correlation between anthropometric measurement, lipid profile, dietary vitamins, serum antioxidants, lipoprotein and lipid peroxides in known cases of 345 elderly hypertensive South Asian aged 56-64 y-A hospital based study. Asian Pac J. Trop. Biomed. (Suppl 1): S189S197.

Mann, T., A.J. Tomiyama, E. Westling, A.M. Lew, B. Samuels and J. Chatman (2007). Medicare's search for effective obesity treatments. Ame. Psychol., 62 (3): 220-33.

Steel, R.G.D. and J.H. Torries (1980). Principle and Procedure of Statistics $2^{\text {nd }}$ Ed. Mc Groo Hill. Book Co. Inc. New York.

Talat, M.A. and E. El-Shahat (2016). Prevalence of overweight and obesity among preparatory school adolescents in Urban Sharkia Governorate, Egypt. Pediatric Ass. Gazette, 64: 20-25

Trinder, P. (1969). Determination of Blood Glucose Using 4- Aminophenazone. J. Clin. Path., 22 : 246.

UNPSD (2014). United Nations Populations Statistical Division. Statistical papers series A United Nations.

Young, D.S. (2000). Effects of Drugs on Clinical Laboratory Tests $5^{\text {th }}$ Ed. (ISBN 9781-8908-8324-9), AACC Press, Washington, DC.

Young, D.S. and R.B. Friedman (2001). Effects of Disease on Clinical Laboratory Tests $4^{\text {th }}$ Ed. (ISBN 978-1-8908-8345-4), AACC Press, Washington, DC. 
العلاقة بين الغذاء المتناول وأمراض القلب والأوعية الدموية لبعض المرضى في مدينة الزقازيق، محافظة الثرقية

\author{
شيماء محمد منصور - عاطف حلمي جرجس - مديحة عبدالجواد الثيوي

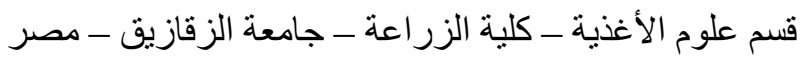

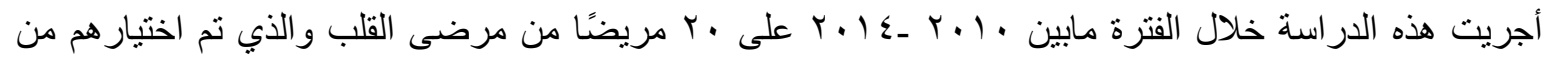

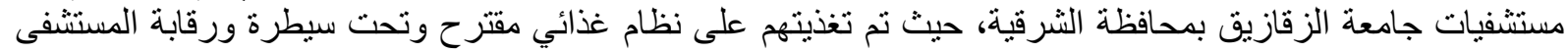

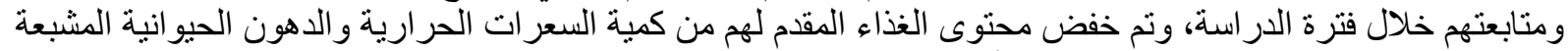

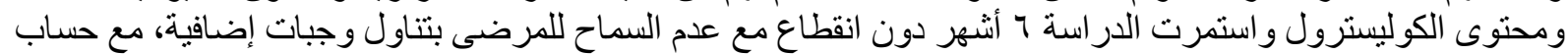

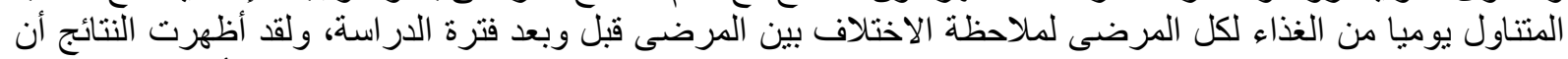

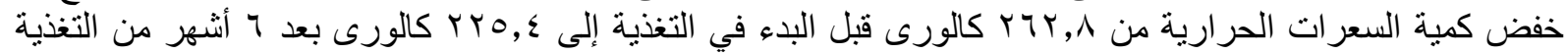

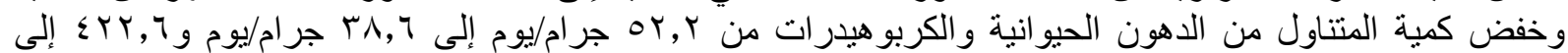

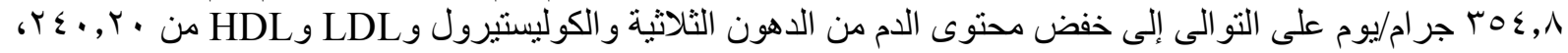

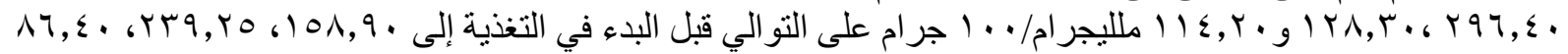

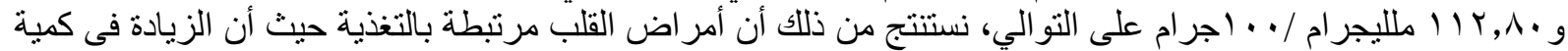

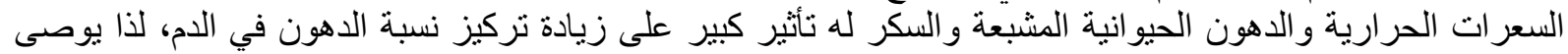

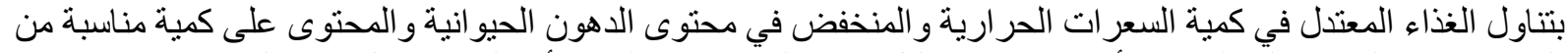

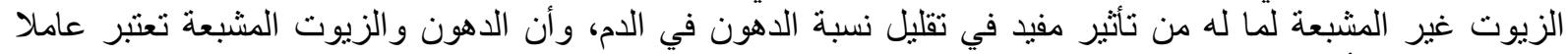

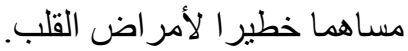

